\title{
Magnetohidrodinamik Fluida Micropolar yang Mengalir Melalui Bola Berpori dengan Pengaruh Magnet
}

\author{
Rahayu Oktavia P., Basuki Widodo, dan Nur Asiyah \\ Departemen Matematika, Fakultas Matematika, Komputasi, dan Sains Data, Institut Teknologi \\ Sepuluh Nopember (ITS) \\ e-mail:b_widodo@matematika.its.ac.id,nora@matematika.its.ac.id
}

\begin{abstract}
Abstrak-Perkembangan penelitian mengenai energi sangat diperlukan. Efisiensi penggunaan energi dapat membantu untuk menghemat sumber daya alam. Fluida merupakan salah satu studi ilmu yang membahas mengenai energi. Namun penelitian secara fisik membutuhkan biaya yang besar. Oleh karena itu digunakan pemodelan matematika untuk menyelesaikan permasalahan tersebut. Penelitian ini mengkaji mengenai magnetohidrodinamik fluida micropolar yang melewati bola berpori dengan pengaruh magnet dan konveksi paksa. Digunakan persamaan pembangun yang didapat dari persamaan kontinuitas, persamaan momentum, persamaan momentum angular, dan persamaan energi. Persamaan pembangun berbentuk persamaan parsial dua dimensi. Persamaan dimensional ditransformasikan kedalam persamaan non dimensional, kemudian dirubah kedalam persamaan similaritas dan diselesaikan secara numerik dengan menggunakan skema Keller-Box. Hasil simulasi menunjukkan bahwa profil kecepatan menurun ketika parameter magnetik meningkat. Profil mikro rotasi dan temperatur meningkat seiring meningkatnya parameter magnetik.
\end{abstract}

Kata Kunci-Magnetohidrodinamik, Fluida micropolar, Bola berpori bermagnet, Keller-Box.

\section{PENDAHULUAN}

$\mathrm{E}$ NERGI merupakan salah satu kebutuhan pokok manusia. Akan tetapi sumber daya alam semakin lama semakin menipis dan dapat menyebabkan kelangkaan, terutama sumber daya yang tidak dapat diperbarui seperti gas alam. Saat ini penelitian mengenai energi menarik untuk dikembangkan. Kemajuan teknologi dan juga industri mendorong peneliti untuk mengoptimalkan pemanfaatan energi. Dalam proses manufaktur industri kerap kali digunakan prinsip perpindahan panas pada fluida contohnya yaitu lembaran logam dan polimer [1]. Fluida merupakan zat yang dapat berubah bentuk secara kontinu jika dikenai tegangan geser [2]. Pada kenyataannya penelitian mengenai fluida secara fisik membutuhkan fasilitas yang canggih dan biaya yang mahal. Oleh karena itu dibutuhkan studi ilmu yang dapat merepresentasikan permasalahan tersebut. Studi ilmu yang membahas mengenai fluida salah satunya adalah pemodelan matematika. Dalam bidang matematika, perpindahan panas pada suatu permukaan benda telah banyak banyak diteliti, dimana salah satunya yaitu dengan memanfaatkan magnet [3].

Magnetohidrodinamik merupakan studi ilmu yang mempelajari tentang aliran fluida penghantar arus listrik akibat adanya pengaruh medan magnet [4]. Berdasarkan tegangan gesernya fluida dibagi menjadi dua yaitu fluida
Newtonian dan non-Newtonian [5]. Fluida micropolar merupakan salah satu contoh dari fluida non-newtonian yang memiliki karakteristik yaitu berstruktur mikro, bersifat kaku dan dapat berotasi secara acak atau yang disebut dengan mikro rotasi [6]. Dalam bidang teknik, keunikan fluida micropolar memiliki potensi yang tinggi untuk dikembangkan [7].

Penelitian mengenai fluida micropolar telah dilakukan oleh Zainul Haque [8] pada tahun 2011. Dalam penelitiannya Zainul mengkaji mengenai efek dari parameter terhadap kecepatan, mikro rotasi, suhu, dan medan konsentrasi pada fluida yang diberi magnet dengan konveksi bebas. Pada tahun 2015 Anggriani [9] mengembangkan penelitian mengenai magnetohidrodinamik pada fluida micropolar yang diberi magnet. Aliran fluida micropolar melewati bola berpori. Dalam penelitian tersebut dikaji mengenai pengaruh parameter magnetik dan parameter permeabilitas terhadap laju kecepatan fluida dan mikro rotasi. Hasil penelitian menunjukkan bahwa semakin besar parameter magnetik yang diberikan maka kecepatan mikro rotasi pada aliran pekat semakin menurun, sedangkan pada aliran agak pekat semakin meningkat.

Penelitian yang telah dilakukan untuk saat ini masih terbatas pada pemberian magnet pada fluida. Oleh karena Pada penelitian ini akan dikembangkan mengenai magnetohidro-dinamik pada fluida micropolar yang melalui bola berpori yang mengandung magnet dengan pengaruh konveksi paksa. Konveksi paksa yang diberikan berupa panas dan menyebar dari segala arah. Berikut merupakan ilustrasi dari permasalahan.

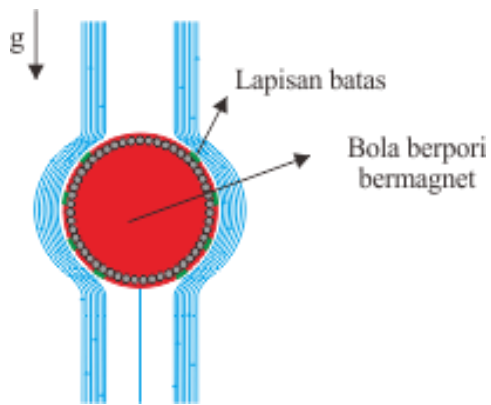

Gambar 1. Model aliran fluida micropolar yang melalui bola berpori dengan konveksi paksa.

Dalam penelitian ini akan dikaji mengenai pengaruh parameter magnetik terhadap kecepatan, mikro rotasi, dan temperatur. Model matematika yang terbentuk diselesaikan secara numerik dengan menggunakan skema Keller-Box 


\section{MODEL MATEMATIKA}

Fluida mengalir dari bawah ke atas dan kemudian melewati bola berpori yang dalam keadaan diam.

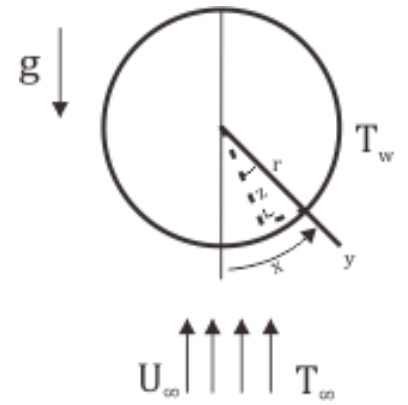

Gambar 2. Model aliran fluida micropolar yang melalui bola berpori dengan koordinat 3 dimensi.

Gambar 2 menunjukkan koordinat 3 dimensi pada bola. Fluida yang mengalir mendekati bola akan mendapat pengaruh gaya magnet yang terdapat pada bola. Selain itu tumbukan yang terjadi antara fluida dan permukaan bola mengakibatkan gesekan yang kemudian membentuk suatu lapisan tipis disepanjang permukaan bola. Lapisan ini dinamakan dengan lapisan batas [5].

\section{A. Persamaan Dimensional}

Persamaan pembangun yang digunakan didapat dari persamaan kontinuitas, persamaan momentum, persamaan momentum angular, dan persamaan energi. Persamaan Kontinuitas didapat dari Hukum Konservasi Massa yang menyatakan bahwa laju perubahan massa terhadap waktu sama dengan nol [10]. Persamaan momentum didapat dari Hukum II Newton yang menyatakan bahwa besarnya laju perubahan momentum sama dengan jumlah semua gaya yang bekerja pada sistem. Persamaan momentum angular didapat dari Hukum Kekekalan momentum angular, sedangkan persamaan energi didapat dari Hukum Termodinamika I. Berikut merupakan persamaan pembangun yang didapatkan Persamaan Kontinuitas

$$
\begin{array}{r}
\frac{\partial \bar{r} \bar{u}}{\partial \bar{x}}+\frac{\partial \bar{r} \bar{v}}{\partial \bar{y}}+\frac{\partial \bar{r} \bar{w}}{\partial \bar{z}} \\
=0
\end{array}
$$

Persamaan Momentum

Searah sumbu-x

$$
\begin{gathered}
\rho\left[\frac{\partial \bar{u}}{\partial \bar{t}}+\bar{u} \frac{\partial \bar{u}}{\partial \bar{x}}+\bar{v} \frac{\partial \bar{u}}{\partial \bar{y}}+\bar{w} \frac{\partial \bar{u}}{\partial \bar{z}}\right]=-\frac{\partial \bar{p}}{\partial \bar{x}}+(\mu+\kappa) \\
{\left[\frac{\partial^{2} \bar{u}}{\partial \bar{x}^{2}}+\frac{\partial^{2} \bar{u}}{\partial \bar{y}^{2}}+\frac{\partial^{2} \bar{u}}{\partial \bar{z}^{2}}\right]+\rho \beta\left(\bar{T}-T_{\infty}\right) g_{x}+\kappa \frac{\partial \bar{N}}{\partial \bar{y}}+} \\
+\frac{\mu}{K^{*}} \bar{u}
\end{gathered}
$$

Searah sumbu-y

$$
\begin{aligned}
\rho\left[\frac{\partial \bar{v}}{\partial \bar{t}}+\bar{u} \frac{\partial \bar{v}}{\partial \bar{x}}+\bar{v} \frac{\partial \bar{v}}{\partial \bar{y}}+\bar{w} \frac{\partial \bar{v}}{\partial \bar{z}}\right]=-\frac{\partial \bar{p}}{\partial \bar{y}}+(\mu+\kappa) \\
{\left[\frac{\partial^{2} \bar{v}}{\partial \bar{x}^{2}}+\frac{\partial^{2} \bar{v}}{\partial \bar{y}^{2}}+\frac{\partial^{2} \bar{v}}{\partial \bar{z}^{2}}\right]+\rho \beta\left(\bar{T}-T_{\infty}\right) g_{y}-\kappa \frac{\partial \bar{N}}{\partial \bar{x}}+} \\
+\frac{\mu}{K^{*}} \bar{v} B_{0}^{2} \bar{v}
\end{aligned}
$$

Searah sumbu-z

$$
\rho\left[\frac{\partial \bar{w}}{\partial \bar{t}}+\bar{u} \frac{\partial \bar{w}}{\partial \bar{x}}+\bar{v} \frac{\partial \bar{w}}{\partial \bar{y}}+\bar{w} \frac{\partial \bar{w}}{\partial \bar{z}}\right]=-\frac{\partial \bar{p}}{\partial \bar{z}}+(\mu+\kappa)
$$

$$
\begin{gathered}
{\left[\frac{\partial^{2} \bar{w}}{\partial \bar{x}^{2}}+\frac{\partial^{2} \bar{w}}{\partial \bar{y}^{2}}+\frac{\partial^{2} \bar{w}}{\partial \bar{z}^{2}}\right]+\rho \beta\left(\bar{T}-T_{\infty}\right) g_{z}} \\
+\frac{\mu}{K^{*}} \bar{w}
\end{gathered}
$$

Persamaan Momentum Angular

$$
\begin{gathered}
\rho J\left[\frac{\partial \bar{N}}{\partial \bar{t}}+\bar{u} \frac{\partial \bar{N}}{\partial \bar{x}}+\bar{v} \frac{\partial \bar{N}}{\partial \bar{y}}+\bar{w} \frac{\partial \bar{N}}{\partial \bar{z}}\right] \\
=-\gamma\left[\frac{\partial^{2} \bar{N}}{\partial \bar{x}^{2}}+\frac{\partial^{2} \bar{N}}{\partial \bar{y}^{2}}+\frac{\partial^{2} \bar{N}}{\partial z^{2}}\right] \\
-\kappa\left[2 \bar{N}+\frac{\partial \bar{u}}{\partial \bar{y}}-\frac{\partial \bar{w}}{\partial \bar{y}}-\frac{\partial \bar{v}}{\partial \bar{x}}-\frac{\partial \bar{w}}{\partial \bar{x}}+\frac{\partial \bar{u}}{\partial \bar{z}}\right. \\
\left.+\frac{\partial \bar{v}}{\partial \bar{z}}\right]
\end{gathered}
$$

Persamaan Energi

$$
\begin{gathered}
\rho c_{p}\left[\frac{\partial \bar{T}}{\partial \bar{t}}+\bar{u} \frac{\partial \bar{T}}{\partial \bar{x}}+\bar{v} \frac{\partial \bar{T}}{\partial \bar{y}}+\bar{w} \frac{\partial \bar{T}}{\partial \bar{z}}\right] \\
=c\left[\frac{\partial^{2} \bar{T}}{\partial \bar{x}^{2}}+\frac{\partial^{2} \bar{T}}{\partial \bar{y}^{2}}\right. \\
\left.+\frac{\partial^{2} \bar{T}}{\partial \bar{z}^{2}}\right]
\end{gathered}
$$

Dengan kondisi batas

$t<0: \bar{u}=\bar{v}=\bar{w}=\bar{N}=0, \bar{T}=T_{\infty}$ untuk setiap $\bar{x}, \bar{y}, \bar{z}$

$t \geq 0: \bar{u}=\bar{v}=\bar{w}=0, \bar{N}=-n \frac{\partial \bar{u}}{\partial \bar{y}}, \bar{T}=T_{w}$ untuk $\bar{y}=0$ $\bar{u}=\bar{u}_{e}(\bar{x}), \bar{N}=0, \bar{T}=T_{\infty}$ untuk $\bar{y} \rightarrow \infty$

Dengan $\bar{u}, \bar{v}$, dan $\bar{w}$ merupakan kecepatan fluida, $\rho$ merupakan densitas fluida, $\bar{p}$ merupakan tekanan, $\mu$ adalah viskositas dinamik, $\kappa$ adalah vortex, $\beta$ adalah koefisien ekspansi panas, $\bar{T}$ adalah suhu, $g$ merupakan gaya gravitasi, $\bar{N}$ adalah mikro rotasi, dan $\gamma$ adalah spin gradien.

Pada penelitian ini permasalahan yang akan dikaji salah satunya adalah kecepatan aliran fluida. Oleh karena itu permukaan bola yang terlihat adalah 2 dimensi dimana sumbu $\mathrm{z}$ diabaikan. Berikut merupakan koordidat bola 2 dimensi

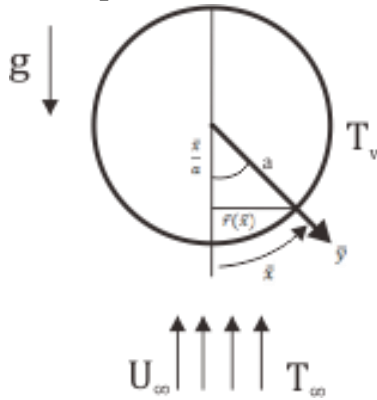

Gambar 3. Model aliran fluida micropolar yang melalui bola berpori dengan koordinat 2 dimensi.

Persamaan pembangun dimensional 2 dimensi yang terbentuk adalah

Persamaan Kontinuitas

$\frac{\partial \bar{r} \bar{u}}{\partial \bar{x}}+\frac{\partial \bar{r} \bar{v}}{\partial \bar{y}}$

$=0$

Persamaan Momentum

Searah sumbu-x

$$
\begin{aligned}
\rho\left[\frac{\partial \bar{u}}{\partial \bar{t}}+\bar{u} \frac{\partial \bar{u}}{\partial \bar{x}}+\bar{v}\right. & \left.\frac{\partial \bar{u}}{\partial \bar{y}}\right] \\
& =-\frac{\partial \bar{p}}{\partial \bar{x}}+(\mu+\kappa)+\left[\frac{\partial^{2} \bar{u}}{\partial \bar{x}^{2}}+\frac{\partial^{2} \bar{u}}{\partial \bar{y}^{2}}\right]
\end{aligned}
$$




$$
\begin{aligned}
& +\rho \beta\left(\bar{T}-T_{\infty}\right) g_{x}+\kappa \frac{\partial \bar{N}}{\partial \bar{y}}+\sigma B_{0}^{2} \bar{u} \\
& +\frac{\mu}{K^{*}} \bar{u}
\end{aligned}
$$

Searah sumbu-y

$$
\begin{gathered}
\rho\left[\frac{\partial \bar{v}}{\partial \bar{t}}+\bar{u} \frac{\partial \bar{v}}{\partial \bar{x}}+\bar{v} \frac{\partial \bar{v}}{\partial \bar{y}}\right]=-\frac{\partial \bar{p}}{\partial \bar{y}}+(\mu+\kappa)+\left[\frac{\partial^{2} \bar{v}}{\partial \bar{x}^{2}}+\frac{\partial^{2} \bar{v}}{\partial \bar{y}^{2}}\right] \\
+\rho \beta\left(\bar{T}-T_{\infty}\right) g_{y}+\kappa \frac{\partial \bar{N}}{\partial \bar{x}}+\sigma B_{0}^{2} \bar{u} \\
+\frac{\mu}{K^{*}} \bar{v}
\end{gathered}
$$

Persamaan Momentum Angular

$$
\begin{aligned}
& \rho\left[\frac{\partial \bar{N}}{\partial \bar{t}}+\bar{u} \frac{\partial \bar{N}}{\partial \bar{x}}+\bar{v} \frac{\partial \bar{N}}{\partial \bar{y}}\right]=\gamma\left[\frac{\partial^{2} \bar{N}}{\partial \bar{x}^{2}}+\frac{\partial^{2} \bar{N}}{\partial \bar{y}^{2}}\right]- \\
& \kappa\left[2 \bar{N}+\frac{\partial \bar{u}}{\partial \bar{y}}\right. \\
& \left.-\frac{\partial \bar{v}}{\partial \bar{x}}\right]
\end{aligned}
$$

Persamaan Energi

$$
\begin{aligned}
\rho c_{p}\left[\frac{\partial \bar{T}}{\partial \bar{t}}+\bar{u} \frac{\partial \bar{T}}{\partial \bar{x}}\right. & \left.+\bar{v} \frac{\partial \bar{T}}{\partial \bar{y}}\right] \\
& =c\left[\frac{\partial^{2} \bar{T}}{\partial \bar{x}^{2}}+\frac{\partial^{2} \bar{T}}{\partial \bar{y}^{2}}\right]
\end{aligned}
$$

Dengan kondisi batas

$$
\begin{aligned}
t<0: \bar{u} & =\bar{v}=\bar{N}=0, \bar{T}=T_{\infty} \text { untuk setiap } \bar{x}, \bar{y} \\
t \geq 0: \bar{u} & =\bar{v}=0, \bar{N}=-n \frac{\partial \bar{u}}{\partial \bar{y}}, \bar{T}=T_{w} \text { untuk } \bar{y}=0 \\
\bar{u} & =\bar{u}_{e}(\bar{x}), \bar{N}=0, \bar{T}=T_{\infty} \text { untuk } \bar{y} \rightarrow \infty
\end{aligned}
$$

\section{B. Persamaan Non-Dimensional}

Pada persamaan dimensional terdapat satuan dari masingmasing besaran yang dapat mempersulit penyelaian karena perbedaan aturan pada setiap wilayah. Oleh karena itu persamaan dimensional ditransformasikan kedalam bentuk non dimensional. Persamaan non-dimensioanal didapat dengan menggunakan variabel non dimensional dan parameter non dimensional. Berikut merupakan variabel dan perameter yang digunakan [11]:

$$
\begin{gathered}
x=\frac{\bar{x}}{a}, y=\frac{R e^{\frac{1}{2}} \bar{y}}{a}, r(x)=\frac{\bar{r}(\bar{x})}{a}, t=\frac{U_{\infty} \bar{t}}{a}, u=\frac{\bar{u}}{U_{\infty}}, v \\
=\frac{R_{e}^{\frac{1}{2}} \bar{v}}{U_{\infty}} \\
p=\frac{\bar{p}}{\rho U_{\infty}^{2}}, T=\frac{\bar{T}-T_{\infty}}{T_{w}-T_{\infty}}, N=\frac{R e^{\frac{1}{2}} a \bar{N}}{U_{\infty}}, g_{x}=-g \sin \left(\frac{\bar{x}}{a}\right) \\
g_{y} \\
=g \cos \left(\frac{\bar{x}}{a}\right)
\end{gathered}
$$

Dengan parameter non-dimensional :

$$
\begin{gathered}
M=\frac{a \sigma B_{0}^{2}}{\rho U_{\infty}}, \alpha=\frac{G r}{R e}, G r=\frac{g \beta\left(T_{w}-T_{\infty}\right) a^{3}}{v^{2}}, \operatorname{Pr}=\frac{v \rho C_{p}}{c} \\
\phi=\frac{a \mu}{\rho U_{\infty} K^{*}}, K \\
=\frac{\kappa}{\mu}
\end{gathered}
$$

Dengan $M$ adalah parameter magnetik, $\alpha$ adalah konveksi paksa, $G r$ adalah bilangan Grashof, $P r$ adalah bilangan prandtl, $\phi$ adalah parameter porositas, dan $K$ adalah parameter micropolar.
Kemudian untuk mendapatkan persamaan nondimensional maka dilakukan substitusi Persamaan (12) dan (13) ke Persamaan (7) - (11). Persamaan non-dimensional yang diperoleh adalah sebagai berikut

Persamaan Kontinuitas

$\frac{\partial u}{\partial x}+\frac{\partial v}{\partial y}$

$=0$

Persamaan Momentum

Searah sumbu-x

$\left[\frac{\partial u}{\partial t}+u \frac{\partial u}{\partial x}+v \frac{\partial u}{\partial y}\right]=-\frac{\partial p}{\partial x}+\frac{(1+K)}{R e} \frac{\partial^{2} u}{\partial x^{2}}+(1+K)$

$\frac{\partial^{2} u}{\partial y^{2}}-\alpha T \sin (x)+K \frac{\partial N}{\partial y}$

Searah sumbu-y

$$
+(M+\phi) u
$$

$$
\begin{aligned}
\frac{1}{R e}\left[\frac{\partial v}{\partial t}+u \frac{\partial v}{\partial x}+\right. & \left.v \frac{\partial v}{\partial y}\right]=-\frac{\partial p}{\partial y}+\frac{(1+K)}{R e} \frac{\partial^{2} v}{\partial x^{2}}+(1+K) \\
\frac{\partial^{2} v}{\partial y^{2}}+\alpha T \cos (x) & +K \frac{\partial N}{\partial x} \\
& +(M+\phi) v
\end{aligned}
$$

Persamaan Momentum Angular

$$
\begin{aligned}
& {\left[\frac{\partial N}{\partial t}+u \frac{\partial N}{\partial x}+v \frac{\partial N}{\partial y}\right]=\left(1+\frac{K}{2}\right)\left[\frac{1}{R e} \frac{\partial^{2} N}{\partial x^{2}}+\frac{\partial^{2} N}{\partial y^{2}}\right]} \\
& -K\left[2 N+\frac{\partial u}{\partial y}\right. \\
& \left.-\frac{1}{R e} \frac{\partial v}{\partial x}\right]
\end{aligned}
$$

Persamaan Energi

$$
\begin{aligned}
{\left[\frac{\partial T}{\partial t}+u \frac{\partial T}{\partial x}+v \frac{\partial T}{\partial y}\right] } & \\
= & \frac{1}{\operatorname{Pr}} \frac{1}{R e} \frac{\partial^{2} T}{\partial x^{2}}+\frac{1}{\operatorname{Pr}} \frac{\partial^{2} T}{\partial y^{2}}
\end{aligned}
$$

Dengan kondisi batas :

$t<0: u=v=N=T=0$ untuk setiap $x, y$

$t \geq 0: u=v=0, N=-n \frac{\partial u}{\partial y}, T=1$ ketika $y=0$

$$
u=u_{e}(x), N=T=0 \text { ketika } y \rightarrow \infty
$$

\section{Pendekatan Lapisan Batas dan Fungsi Alir}

Pada penelitian ini aliran fluida melewati bola pada permukaan $x=0$ sehingga digunakan pendekatan lapisan batas dimana diasumsikan bahwa $R e=0$. Selanjutnya diperkenalkan teori potensial 2 dimensi dengan $w=0$. Maka untuk menghubungkan kecepatan pada dua sumbu digunakan fungsi alir dengan variabel sebagai berikut :

$$
\begin{aligned}
u= & \frac{1}{r} \frac{\partial \psi}{\partial y}, v \\
& =-\frac{1}{r} \frac{\partial \psi}{\partial x}
\end{aligned}
$$

Dengan menggunakan Persamaan (19) akan didapatkan fungsi alir untuk model matematika pada sistem. Persamaan (19) disubstitusikan ke dalam Persamaan (14) - (18) sehingga di dapatkan Persamaan sebagai berikut

Persamaan Momentum

$$
\begin{gathered}
\frac{1}{r} \frac{\partial^{2} \psi}{\partial t \partial y}+\frac{1}{r^{2}} \frac{\partial \psi}{\partial y} \frac{\partial^{2} \psi}{\partial x \partial y}-\frac{1}{r^{3}} \frac{\partial r}{\partial x}\left(\frac{\partial \psi}{\partial y}\right)^{2}-\frac{1}{r^{2}} \frac{\partial \psi}{\partial x} \frac{\partial^{2} \psi}{\partial y^{2}} \\
=\frac{\partial u_{e}}{\partial x} u_{e}
\end{gathered}
$$


$-(M+\phi)\left(u_{e}-\frac{1}{r} \frac{\partial \psi}{\partial y}\right)+\frac{(1+K)}{r} \frac{\partial^{3} \psi}{\partial y^{3}}-\alpha T \sin (x)$

$+K \frac{\partial N}{\partial y}$

Persamaan Momentum Angular

$\frac{\partial N}{\partial t}+\frac{1}{r} \frac{\partial \psi}{\partial y} \frac{\partial N}{\partial x}-\frac{1}{r} \frac{\partial \psi}{\partial x} \frac{\partial N}{\partial y}=\left(1+\frac{K}{2}\right)+\frac{\partial^{2} N}{\partial y^{2}}$

$-K(2 N$

$\left.+\frac{\frac{1}{r} \partial^{2} \psi}{\partial y^{2}}\right)$

Persamaan Energi

$\frac{\partial T}{\partial t}+\frac{1}{r} \frac{\partial \psi}{\partial y} \frac{\partial T}{\partial x}-\frac{1}{r} \frac{\partial \psi}{\partial x} \frac{\partial T}{\partial y}$

$$
=\frac{1}{\operatorname{Pr}} \frac{\partial^{2} T}{\partial y^{2}}
$$

Dengan kondisi batas

$$
\begin{gathered}
t<0: \psi=\frac{\partial \psi}{\partial y}=N=T=0 \text { untuk setiap } x, y \\
t \geq 0: \psi=\frac{\partial \psi}{\partial y}=0, N=-n \frac{\partial^{2} \psi}{\partial y^{2}}, T=1 \text { ketika } y=0 \\
\frac{\partial \psi}{\partial y}=u_{e}(x), N=T=0 \text { ketika } y \rightarrow \infty
\end{gathered}
$$

\section{Persamaan Similaritas}

Persamaan dengan menggunakan fungsi alir kemudian dirubah menjadi persamaan similaritas. Adapun untuk mendapatkan persamaan similaritas dilakukan dengan langkah-langkah sebagai berikut :

Pada Persamaan small time $\left(t \leq t^{*}\right)$ dilakukan pemisalan dengan menggunakan

$$
\begin{aligned}
\frac{\partial f}{\partial \eta} & =f^{\prime}, \frac{\partial s}{\partial \eta}=s^{\prime}, \frac{\partial h}{\partial \eta} \\
& =h^{\prime}
\end{aligned}
$$

dan

$$
\left.\begin{array}{c}
\psi=t^{\frac{1}{2}} u_{e}(x) r(x) f(x, \eta, t) \\
T=s(x, \eta, t) \\
\eta=\frac{y}{t^{\frac{1}{2}}} \\
N=t^{-\frac{1}{2}} u_{e}(x) h(x, \eta, t)
\end{array}\right\}
$$

Dengan mensubstitusi Persamaan (23) dan (24) kedalam Persamaan (20) - (22) maka didapatkan persamaan sebagai berikut :

Persamaan Momentum

$$
\begin{gathered}
(1+K) f^{\prime \prime \prime}+\frac{\eta}{2} f^{\prime \prime}+K h^{\prime}+(M+\phi) t\left(f^{\prime}-1\right)+\frac{2}{3} \alpha t s \\
+ \\
\frac{3}{2}\left(1-\left(f^{\prime}\right)^{2}+f \cdot f^{\prime \prime}\right) \\
=t \frac{\partial f^{\prime}}{\partial t}
\end{gathered}
$$

Persamaan Momentum Angular

$$
\begin{aligned}
\left(1+\frac{K}{2}\right) h^{\prime \prime}+\frac{\eta}{2} & h^{\prime}+\frac{1}{2} h+\frac{3}{2} t\left(f h^{\prime}-h f^{\prime}\right) \\
& =t \frac{\partial h}{\partial t}
\end{aligned}
$$

Persamaan Energi

$$
\begin{aligned}
\frac{1}{2} \eta \operatorname{Pr} s^{\prime}+s^{\prime \prime}+ & \frac{3}{2} \operatorname{Pr} f s^{\prime} \\
& =\operatorname{Pr} t \frac{\partial s}{\partial t}
\end{aligned}
$$

Dengan kondisi batas

$$
\begin{gathered}
t<0: f=\frac{\partial f}{\partial \eta}=h=s=0 \text { untuk setiap } x, \eta \\
t \geq 0: f=\frac{\partial f}{\partial \eta}, h=-n \frac{\partial^{2} f}{\partial \eta^{2}}, s=1 \text { ketika } \eta=0 \\
\frac{\partial f}{\partial \eta}=1, h=0, s=0 \text { ketika } \eta \rightarrow \infty
\end{gathered}
$$

\section{E. Keller-Box}

Penyelesaian numerik dengan menggunakan Keller-Box dilakukan dengan langkah-langkah sebagai berikut:

1. Merubah Persamaan orde tinggi menjadi Persamaan orde pertama dengan cara menyelaraskan notasi.

2. Diskritisasi dengan menggunakan metode numerik beda hingga Keller-Box.

3. Melinierisasi model dengan menggunakan metode Newton.

4. Membentuk matriks tridiagonal dengan menggunakan teknik eliminasi blok.

\section{ANALISIS DAN PEMBAHASAN}

Penyelesaian numerik dari pengaruh parameter magnetik dapat diselesaikan dengan cara memasukkan beberapa nilai pada parameter magnetik. Pada simulasi ini diberikan kondisi awal dengan nilai partisi $\eta=60$, partisi waktu $t=20, \Delta \eta=$ $l_{j}=0.1, \Delta t=k^{n}=0.05, t=20$, dan konsentrasi $n=0,1$. Pemilihan parameter didapat dari bahan yang akan digunakan. Berikut merupakan daftar bahan yang digunakan dalam mencari nilai parameter dengan menggunakan nilai $B_{0}=0.1, U_{\infty}=1$, dan $a=0.1$.

Tabel 1.

Perhitungan Parameter Magnetik

\begin{tabular}{cccc}
\hline \hline Bahan & $\rho\left(\frac{\mathrm{kg}}{\mathrm{m}^{3}}\right)$ & $\sigma$ & $\mathrm{M}$ \\
\hline Besi & 7870 & $1,04 \cdot 10^{7}$ & 1,3 \\
Baja & 8860 & $1,6 \cdot 10^{7}$ & 1,8 \\
Kuningan & 8400 & $1,6 \cdot 10^{7}$ & 1,9 \\
\hline \hline
\end{tabular}

Berikut merupakan hasil simulasi pada profil kecepatan:

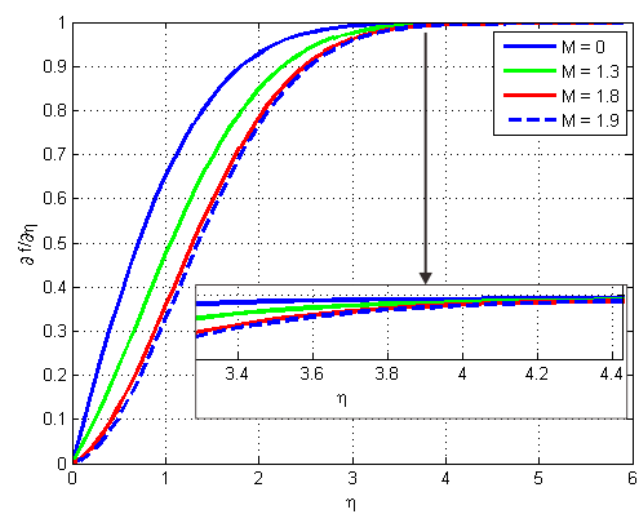

Gambar 4. Pengaruh variasi parameter magnetik terhadap kecepatan dengan $K=1, \phi=1, \operatorname{Pr}=1$, dan $\alpha=0$.

Gambar 4 menunjukkan pemberian variasi parameter magnetik mengakibatkan pada saat $0 \leq \eta \leq 4.4$ aliran fluida mengalami perbedaan penurunan kecepatan. Berdasarkan rumus matematis dari parameter magnetik diketahui bahwa 
parameter magnetik sebanding dengan kuadrat gaya Lorenz $\left(B_{0}\right)$ dan berbanding terbalik dengan densitas fluida $(\rho)$. Hal ini menunjukkan bahwa semakin bertambahnya nilai parameter magnetik maka gaya Lorenz yang bekerja pada bola berpori akan semakin besar. Sedangkan densitas fluida akan semakin kecil. Medan magnet yang terdapat pada bola berpori menyebabkan gaya tolak terhadap aliran fluida. Oleh karena itu semakin besar parameter magnetik yang diberikan kecepatan fluida akan semakin menurun.

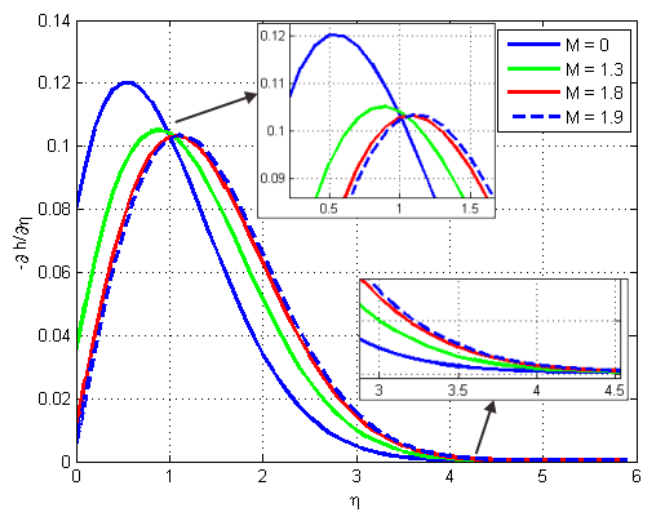

Gambar 5. Pengaruh variasi parameter magnetik terhadap mikro rotasi dengan $K=1, \phi=1, \operatorname{Pr}=1$, dan $\alpha=0$

Gambar 5 menunjukkan bahwa terjadi kenaikan dan penurunan profil mikro rotasi. Ketika $1,5 \leq \eta \leq 4,5$ terjadi kenaikan pergerakan mikro rotasi. Akan tetapi ketika berada pada $1,5<\eta \leq 0$ terjadi penurunan pergerakan mikro rotasi. Pertambahan parameter magnetik mengakibatkan densitas fluida semakin menurun sehingga kerapatan molekul pada fluida semakin berkurang. Penurunan densitas fluida mengakibatkan pergerakan partikel mikro memiliki ruang yang semakin luas sehingga pergerakan partikel lebih leluasa. Oleh karena itu semakin bertambah parameter magnetik maka semakin meningkat pergerakan mikro rotasi. Selain itu hasil simulasi menunjukkan bahwa pada titik stagnasi $x=0$ dengan konsentrasi bahan $n=0,1$ ketika aliran fluida mengenai bola masih terjadi pergerakan mikro rotasi.

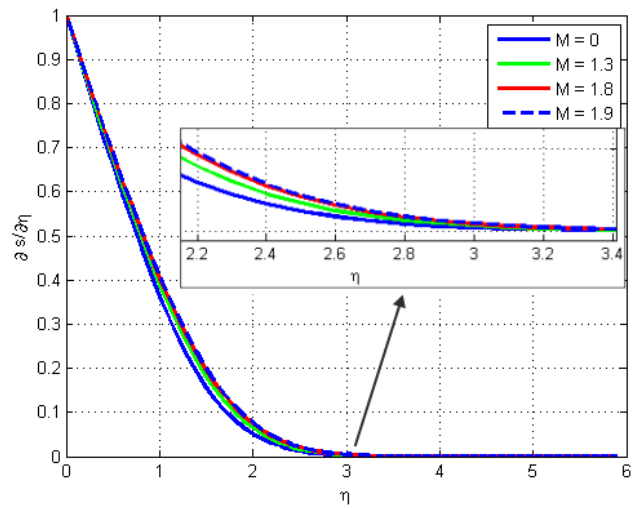

Gambar 6. Pengaruh variasi parameter magnetik terhadap temperatur dengan $K=1, \phi=1, \operatorname{Pr}=1$, dan $\alpha=0$.

Gambar 6 menunjukkan bahwa semakin bertambah parameter magnetik maka profil temperatur semakin meningkat. Kurva temperatur mengalami penurunan dari $s=$ 1 sampai $s \approx 0$. Ketika $0 \leq \eta \leq 3,4$ pemberian variasi parameter magnetik menyebabkan profil temperatur meningkat seiring meningkatnya nilai parameter magnetik. Hal ini terjadi karena energi internal fluida menurun akibat adanya pengaruh medan magnet. Oleh karena itu profil temperatur meningkat ketika parameter magnetik meningkat.

\section{KESIMPULAN}

1. Persamaan pembangun model matematika dari magnetohidrodinamik fluida micropolar yang mengalir melalui bola berpori dengan pengaruh magnet didapat dari persamaan kontinuitas, persamaan momentum, persamaan momentum angular, dan persamaan energi. Dalam persamaan momentum bola berpori yang mengandung magnet mengakibatkan persamaan pada gaya magnet bernilai negatif yang menunjukkan bahwa medan magnet menolak aliran fluida. Persamaan pembangun dimensional ditransformasikan kedalam bentuk non-dimensional, kemudian dilakukan pendekatan lapisan batas, fungsi alir, dan dirubah kedalam bentuk persamaan similaritas.

2. Penyelesaian numerik dari model matematika magnetohidrodinamik fluida micropolar yang mengalir melalui bola berpori dengan pengaruh magnet dilakukan dengan mengubah persamaan orde tinggi menjadi orde pertama. Kemudian melakukan diskritisasi persamaan similaritas dengan menggunakan skema Keller-Box beda hingga pusat. Selanjutnya melinierkan model yang didapat dengan Metode Newton, dan dilanjutkan dengam pembentukan matriks blok tridiagonal.

3. Meningkatnya parameter magnetik mengakibatkan profil kecepatan fluida menurun, mikro rotasi meningkat, dan temperatur meningkat.

\section{DAFTAR PUSTAKA}

T. Abbas, Z., dan Hayat, "Radiation effects on MHD flow in a porous space," Internatonal J. Heat Mass Transf., vol. 51, pp. 1024-1033, 2008.

[2] G. Elseth, "An Experimental Study of Oil/Water Flow in Horizontal Pipes," University College, 2001.

[3] S. A. Khuzaimah, S. S., Yusof, Z. M., Aziz, A. S. A., dan Kechil, "Magnetohydrodynamics Boundary Layer Flows over s Stretching Surface with Radiation Effeact and Embedded in Porous Medium," Int. J. Phys. Math. Sci., vol. 6, no. 8, 2012.

[4] B. Widodo, D. A. Khalimah, F. D. S. Zainal, and C. Imron, "Numerical Solution of Heat Transfer Unsteady Boundary Layer Magnetohydrodynamics in Micropolar Fluid Past a Sphere," Int. J. Far East J. Math. Sci. Publ. House-India, 2015.

[5] B. Widodo, Pemodelan Matematika. ITSPress, 2012.

[6] A. R. M. Kasim, "Convective Boundary Layer Flow of Viscouselastic Fluid," University Technology Malaysia, 2014.

A. C. Eringen, "Theory of micropolar fluidas," 1965.

[8] A. Haque, MD. Z., Alam, MD. M., Ferdows, M., Postelnicu, "Steady MHD Free Convection And Mass Transfer Flow With Constant Heat And Mass Fluxes, Joule Heating And Viscous Dissipation," J. King Saud Univ. Eng. Sci., vol. 24, pp. $71-84$, 2011.

[9] C. Anggriani, Indira., Widodo, B., Imron, "The Unsteady Flow Magnetohydrodynamics in Micropolar Fluid through Porous Sphere," in Proceeding of The Annual Basic Science International Conference, 2015.

[10] B. H. Potter, M. C., Wiggert, D.C., and Ramadan, Mechanics of Fluids $4^{\wedge}$ th Edition. USA, 2015.

[11] N. F. Mohammad, "Unsteady Magnetohydrodynamic Convective Boundary Layer Flow Past a Sphere In Viscous and Micropolar Fluids," University Teknologi Malaysia, 2014. 